\title{
Coexistence of Lung Squamous Cell Carcinoma and Pulmonary Tuberculosis Within a Single Lesion: A Case Report [Erratum]
}

\section{Yu MJ, Li PJ, Liang ZA. Onco Targets Ther. 2021;14:2575-2578.}

The authors have advised the asterisk after Pei-Jun Li is missing from the affiliation list on page 2575 . This error was introduced by the Editorial staff during the publication process. The correct author list and affiliations are shown below.
OncoTargets and Therapy

\section{Publish your work in this journal}

OncoTargets and Therapy is an international, peer-reviewed, open access journal focusing on the pathological basis of all cancers, potential targets for therapy and treatment protocols employed to improve the management of cancer patients. The journal also focuses on the impact of management programs and new therapeutic
${ }^{1}$ West China School of Medicine, Sichuan University, Chengdu, Sichuan, People's Republic of China; ${ }^{2}$ Department of Respiratory and Critical Care Medicine, West China Hospital, Sichuan University, Chengdu, Sichuan, People's Republic of China

*These authors contributed equally to this work

Ming-Jing $\mathrm{Yu}^{1, *}$

Pei-Jun $\mathrm{Li}^{2} *$

Zong-An Liang ${ }^{2}$

agents and protocols on patient perspectives such as quality of life, adherence and satisfaction. The manuscript management system is completely online and includes a very quick and fair peer-review system, which is all easy to use. Visit http://www.dovepress.com/ testimonials.php to read real quotes from published authors. 